$\begin{array}{cc}\text { ACADEMIA ROMÂNĂ } & \text { Rev. Roum. Chim., } \\ \text { Revue Roumaine de Chimie } & \text { 2019, 64(12), 1043-1053 } \\ \text { http://web.icf.ro/rrch/ } & \text { DOI: } 10.33224 / \text { rrch.2019.64.12.04 }\end{array}$

\title{
DNA INTERACTION, PHOTOCLEAVAGE AND THEORETICAL CALCULATIONS OF A RUTHENIUM(II) COMPLEX WITH HYDROXYQUINOLINE DERIVATIVE**
}

\author{
Yaxuan $\mathrm{MI}^{\mathrm{a}}$, Shuang $\mathrm{WANG}^{\mathrm{a}}$, Minghe $\mathrm{WANG}^{\mathrm{a}}$, Zebao ZHENG ${ }^{*}$,b and Xiaolong ZHAO,a \\ ${ }^{\mathrm{a}}$ College of Chemistry \& Environmental Science, Hebei University, Baoding 071002, P.R. China \\ ${ }^{\mathrm{b}}$ College of Chemistry and Chemical Engineering, Taishan University, Taian 271021, P.R. China
}

\begin{abstract}
The interaction of $\left[\mathrm{Ru}(\mathrm{bpy})_{2}(\mathrm{ipq})\right]\left(\mathrm{ClO}_{4}\right)_{2}$ \{bpy $=$ 2,2'-bipyridine, ipq $=2-(1 H$-imidazo $[4,5-f][1,10]$ phenanthrolin-2-yl)quinolin-8-ol\} with calf thymus DNA were investigated by means of DNA viscosity and optical spectroscopic techniques of UV-visible absorption and emission spectral titrations, steadystate emission quenching with ferrocyanide, ethidium bromide competitive binding, and DNA thermal denaturation as well as density functional theoretical calculations. The results suggested that the complex binds to DNA via an classic intercalation mode with enhanced binding strength with respect to the parent analogue $\left[\mathrm{Ru}(\mathrm{bpy})_{2}(\mathrm{ip})\right]\left(\mathrm{ClO}_{4}\right)_{2}\{\mathrm{ip}=$ imidazo[4,5-f][1,10]-phenanthroline $\}$, owing to the larger plan area of ligand ipq as compared to that of ligand ip. Agarose gel electrophoresis showed that the complex also exhibited enhanced DNA photocleavage capacity on pBR 322 plasmid DNA under irradiation at $365 \mathrm{~nm}$ as compared with many hydroxyquinoline-free analogous ruthenium complexes.
\end{abstract}

\section{INTRODUCTION}

Along with the successful clinical use of cisplatin as an anticancer agent over the past few decades, transition metal complexes have been established as an acknowledged subject of the research of chemotherapeutic drugs. ${ }^{1-3}$ Nowadays, not only cisplatin but also other platinum-based drugs including cisplatin, carboplatin and oxaliplatin, are used extensively in the treatment of various human tumors, for example, ovarian, bladder and testicular cancer. Although they are undoubtedly proven to be very effective, they exhibit many side effects such as nephrotoxity, neurotoxity, gastrointestinal toxity etc. ${ }^{4,5}$ Additionally, they display only limited therapeutic activity against the most common tumors, such as colon and breast cancer. ${ }^{4,5}$ So, tremendous efforts are being made to develop alternative metalbased drugs, with fewer or without side effects. In the search of these new drugs, ruthenium complexes have raised great interest, because of their lower toxicity, structural diversity, stronger stability and agreeable physical and photophysical characteristics. ${ }^{1}$ Two ruthenium containing compounds NAMI-A and KP1019 have successfully entered phase II trials for effectively treating colon cancers and metastatic tumors. $^{6-9}$ A ruthenium-arene complex RATAC has been observed with prominent antimetastatic and antiangiogenic activity. ${ }^{10,11}$

On the other hand, there is good evidence that the preferential pharmacological target for a variety of anticancer drugs is DNA, which is a molecule that contains the instructions an organism needs to develop, live and reproduce ${ }^{2}$. The drugs

\footnotetext{
*Corresponding author: longlong_666@sina.com (X.L. Zhao); zhengzebao@163.com (Z.B. Zheng)

${ }^{* *}$ Supplementary information on http: //web.icf.ro/rrch/ or http: //revroum.lew.ro/
} 
have the ability to interfere DNA transcription and replication that are major steps of cell growth and division, triggering apoptosis and cell death. ${ }^{12}$ Thus, understanding drug-DNA interactions is significant to comprehend the mode of action of any anticancer drug targeting DNA. In general, metal complexes bind to DNA via non-covalent ways such as groove, electrostatic and intercalative binding ${ }^{1}$. However, many of useful applications of these complexes require that the complexes bind to DNA through an intercalative mode. For example, the well-known dppz-containing ruthenium(II) polypyridyl complex $\left[\mathrm{Ru}(\mathrm{bpy})_{2}(\mathrm{dppz})\right]^{2+}\{\mathrm{dppz}=$ dipyrido[3,2-a:2',3'-c]phenazine $\}$ and $\left[\mathrm{Ru}(\text { phen })_{2}\right.$ $(\mathrm{dppz})]^{2+}$ \{phen $=[1,10]$ phenanthroline $\}$ emerged as highly promising molecular DNA probes, because of their strong intercalation affinity and the DNA molecular "light-switch" behaviors; ${ }^{13-15}$ some ruthenium(II) polypyridyl complexes $\left[\mathrm{Ru}(\mathrm{bpy})_{2}\right.$ $($ nip $)]^{2+} \quad$ nip $=$ 2-naphthyl-imidazo[4,5-f] $[1,10]$ phenanthroline $\},\left[\mathrm{Ru}(\mathrm{bpy})_{2}(\mathrm{aip})\right]^{2+} \quad\{$ aip $=2-(9-$ anthryl)-imidazo[4,5-f][1,10]phenanthroline $\}$ and $\left[\mathrm{Ru}(\text { bpy })_{2}(\text { pyip })\right]^{2+}\{$ pyip $=2-(1-$ pyrenyl $)$-imidazo $[4,5-f][1,10]$ phenanthroline $\}$ with imidazo[4,5$f][1,10]$ phenanthroline derivatives behave as DNA intercalating agents and DNA condensing agents; ${ }^{16}$ some Bopip (Bopip = 2-(4-(benzyloxy)phenyl)$1 H$-imidazo[4,5-f][1,10]phenanthroline $\}$ and Ciip $\{$ Ciip $=2-(5-C h l o r o-3 a \quad H$-isoindol-3-yl)-1Himidazo[4,5-f][1,10]phenantholine $\}$ ligand containing ruthenium(II) polypyridyl complexes act as DNA intercalators and photocleavers with obvious anticancer activities. ${ }^{17,18}$

As part of our ongoing studies aimed at DNA binding properties based on ruthenium complexes, we present here our interesting findings on a hydroxyquinoline-appended complex: an excellent DNA intercalator with high binding constant of $1.32 \times 10^{6} \mathrm{M}^{-1}$, and an outstanding photocleaver of pBR322 DNA with almost full cleavage under irradiation at $365 \mathrm{~nm}$ for only $15 \mathrm{~min}$.

\section{RESULTS AND DISCUSSION}

\section{UV-vis spectroscopy studies on DNA binding properties}

Electronic absorption spectroscopy is a convenient method for investigating the interaction of complexes with DNA. This interaction is usually accompanied by hypochromism and bathochromism in the metal ligand charge transfer
(MLCT) and ligand bands, which is primarily owing to the intercalation of aromatic chromophores between DNA base pairs. In general, the extent of hypochromism in the UV-visible band parallels the strength of intercalative interaction. ${ }^{19,20}$ The absorption spectra of complex in the absence and presence of increasing concentrations of calf thymus DNA are illustrated in Fig. 1. The spectral behaviors of the complex are shown with obvious hypochromism, $H \%$ (as defined by $H \% \cong 100\left(A_{\text {free }}\right.$ - $\left.A_{\text {bound }}\right) / A_{\text {free }}$, and bathochromism, as indicated by $\Delta \lambda\left(\Delta \lambda=\lambda_{\text {bound }}-\lambda_{\text {freee }}\right)$. Upon increasing amounts of DNA to the constant spectra (saturation), the $H \%$ $(\Delta \lambda)$ values for the ligand bands at $\sim 286$ and $\sim 340 \mathrm{~nm}$ were found to be $23.2 \%(2 \mathrm{~nm})$ and $20.7 \%(3 \mathrm{~nm})$; the $H \%(\Delta \lambda)$ values for the MLCT band at $\sim 460 \mathrm{~nm}$ were found to be $15.6 \%$ ( $3 \mathrm{~nm}$ ). The evident spectral changes observed suggest a strong $\pi-\pi^{*}$ base pairs stacking between the complex and DNA. By monitoring the changes of absorbance at $286 \mathrm{~nm}$ with increasing concentrations of DNA from $0-34.32 \mu \mathrm{M}$, the intrinsic binding constant $K_{\mathrm{b}}$ of the complex was determined to be $1.32 \times 10^{6} \mathrm{M}^{-1}$. The obtained $K_{\mathrm{b}}$ is much higher than or comparable to the $K_{\mathrm{b}}$ values of $2.5 \times$ $10^{4}-1.90 \times 10^{6} \mathrm{M}^{-1}$ that had been previously reported for the analogous parent complex $\left[\mathrm{Ru}(\mathrm{bpy})_{2}(\mathrm{ip})\right]^{2+}$ and many proven classical intercalators as listed in Table 1, but smaller than that of some DNA metallointercalators, such as $\left[\mathrm{Ru}(\mathrm{bpy})_{2}(\text { depip })\right]^{2+} \quad$ depip $\quad=\quad 2-(4-$ (diethoxymethyl)-1H-imidazo[4,5-f][1,10]phenanthroline $)\} \quad\left(K_{\mathrm{b}}=4.5 \times 10^{6} \mathrm{M}^{-1}\right),\left[\mathrm{Ru}(\mathrm{phen})_{2}\right.$ (depip) $]^{2+}\left(K_{\mathrm{b}}=5.0 \times 10^{6} \mathrm{M}^{-1}\right)$ and $\left[\mathrm{Ru}(\mathrm{dmb})_{2}\right.$ (depip) $]^{2+}\left\{\mathrm{dmb}=4,4^{\prime}\right.$-dimethyl-2,2'-bipyridine $\}$ $\left(K_{\mathrm{b}}=4.2 \times 10^{6} \mathrm{M}^{-1}\right)$, also indicating strong binding affinity of the complex to DNA.,21

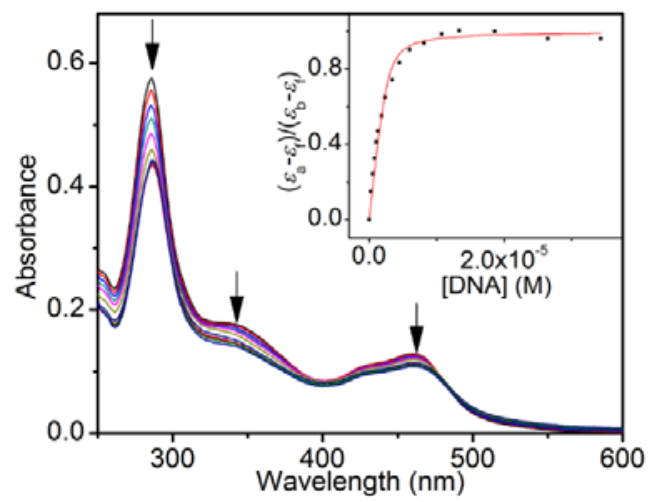

Fig. 1 - Absorption spectra of ruthenium complex upon addition of DNA at room temperature. $[\mathrm{Ru}]=5.43 \mu \mathrm{M}$, $[\mathrm{DNA}]=0-34.32 \mu \mathrm{M}$. Arrow shows the absorbance changes upon the increasing DNA concentrations. Inserted plot: $\left(\varepsilon_{\mathrm{a}}-\varepsilon_{\mathrm{f}}\right) /$ $\left(\varepsilon_{\mathrm{b}}-\varepsilon_{\mathrm{f}}\right)$ vs. [DNA] for the titration of DNA with complex. 
Table 1

Comparisons of DNA binding parameters

\begin{tabular}{lcccc}
\hline Complex & $\boldsymbol{H} \%(\lambda / \mathbf{n m})$ & $\boldsymbol{K}_{\mathbf{b}}\left(\mathbf{M}^{-1}\right)$ & Binding mode & Ref. \\
\hline$\left[\mathrm{Ru}(\mathrm{bpy})_{2}(\mathrm{ipq})\right]^{2+}$ & $23.2(286), 20.7(340), 15.6(460)$ & $1.32 \times 10^{6}$ & intercalation & this work \\
\hline$\left[\mathrm{Ru}(\mathrm{bpy})_{2}(\mathrm{BTCP})\right]^{2+}$ & $36.1(453)$ & $5.25 \times 10^{4}$ & intercalation & $\mathbf{2 2}$ \\
{$\left[\mathrm{Ru}(\mathrm{dmb})_{2}(\mathrm{BTCP})\right]^{2+}$} & $31.5(455)$ & $8.32 \times 10^{4}$ & intercalation & $\mathbf{2 2}$ \\
{$\left[\mathrm{Ru}(\mathrm{phen})_{2}(\mathrm{BTCP})\right]^{2+}$} & $40.3(450)$ & $8.8 \times 10^{4}$ & intercalation & $\mathbf{2 2}$ \\
{$\left[\mathrm{Ru}(\mathrm{ttbpy})_{2}(\mathrm{BTCP})\right]^{2+}$} & $44.8(458)$ & $1.12 \times 10^{5}$ & intercalation & $\mathbf{2 2}$ \\
{$\left[\mathrm{Ru}(\mathrm{bpy})_{2}(\mathrm{CIIP})\right]^{2+}$} & - & $1.77 \times 10^{6}$ & intercalation & $\mathbf{1 7}$ \\
{$\left[\mathrm{Ru}(\mathrm{phen})_{2}(\mathrm{CIIP})\right]^{2+}$} & - & $1.90 \times 10^{6}$ & intercalation & $\mathbf{1 7}$ \\
{$\left[\mathrm{Ru}(\mathrm{dmb})_{2}(\mathrm{CIIP})\right]^{2+}$} & - & $1.26 \times 10^{6}$ & intercalation & $\mathbf{1 7}$ \\
{$\left[\mathrm{Ru}(\mathrm{bpy})_{2}(\mathrm{BOPIP})\right]^{2+}$} & $13.74(462)$ & $3.4 \times 10^{4}$ & intercalation & $\mathbf{1 8}$ \\
{$\left[\mathrm{Ru}(\mathrm{phen})_{2}(\mathrm{BOPIP})\right]^{2+}$} & $14.46(453)$ & $7.1 \times 10^{4}$ & intercalation & $\mathbf{1 8}$ \\
{$\left[\mathrm{Ru}(\mathrm{dmb})_{2}(\mathrm{BOPIP})\right]^{2+}$} & $11.64(467)$ & $2.5 \times 10^{4}$ & intercalation & $\mathbf{1 8}$ \\
{$\left[\mathrm{Ru}(\mathrm{Hdpa})_{2}(\mathrm{BOPIP})\right]^{2+}$} & $15.01(468)$ & $8.3 \times 10^{4}$ & intercalation & $\mathbf{1 8}$ \\
{$\left[\mathrm{Ru}(\mathrm{bpy})_{2}(\mathrm{depip})\right]^{2+}$} & - & $4.5 \times 10^{6}$ & intercalation & $\mathbf{4}$ \\
{$\left[\mathrm{Ru}(\mathrm{phen})_{2}(\mathrm{depip})\right]^{2+}$} & - & $5.0 \times 10^{6}$ & intercalation & $\mathbf{4}$ \\
{$\left[\mathrm{Ru}(\mathrm{dmb})_{2}(\mathrm{depip}]\right]^{2+}$} & - & $4.2 \times 10^{6}$ & intercalation & $\mathbf{4}$ \\
{$\left[\mathrm{Ru}(\mathrm{bpy})_{2}(\mathrm{pip})\right]^{2+}$} & $21.9(458)$ & $4.7 \times 10^{5}$ & intercalation & $\mathbf{2 1}$ \\
{$\left[\mathrm{Ru}(\mathrm{bpy})_{2}(\mathrm{ip})\right]^{2+}$} & $15.5(455)$ & $4.1 \times 10^{4}$ & intercalation & $\mathbf{2 1}$ \\
\hline
\end{tabular}

\section{Luminescence spectroscopy studies on DNA binding properties}

Fluorescence spectroscopy is another technique commonly used to probe the interactions between small ligand molecules and DNA, as the molecular fluorescence is of high sensitivity and selectivity. Changes in emission spectra of the complex with increasing DNA concentrations are shown in Fig. 2. Upon excitation at $460 \mathrm{~nm}$, the complex exhibited moderate luminescence originating predominantly from its ${ }^{3}$ MLCT excited states. When DNA was mixed with the complex solution, the luminescent properties were perturbed. Binding of the complex to DNA was found to increase the fluorescence by a factor of 2.5 times, which is greater than the emission enhancement factor of 1.7 folds for the parent complex $\left[\mathrm{Ru}(\mathrm{bpy})_{2}(\mathrm{ip})\right]^{2+} .^{21}$ The observed emission-increment behavior is because the mobility of the complex is restricted at the binding site and the hydrophobic environment inside the DNA helix reduces the accessibility of solvent water molecules to the complex, leading to a decrease of the vibrational modes of relaxation. ${ }^{17}$ The $K_{\mathrm{b}}$ value of the complex can be also obtained using emission titration according to Bard-TorpMurphy equation. The value of $K_{\mathrm{b}}$ was determined as $2.00 \times 10^{6} \mathrm{M}^{-1}(s=1.79)$, which is well in agreement with the fluorescence titrations.

The Steady-state emission quenching experiments with $\mathrm{K}_{4}\left[\mathrm{Fe}(\mathrm{CN})_{6}\right]$ as a quencher can be used to observe how well the binders can be protected by bound DNA. As illustrated in Fig. 3, in the absence of DNA, the emission of the complex was efficiently quenched by $\left[\mathrm{Fe}(\mathrm{CN})_{6}\right]^{4-}$, but when bound to DNA, the quenching efficiency of

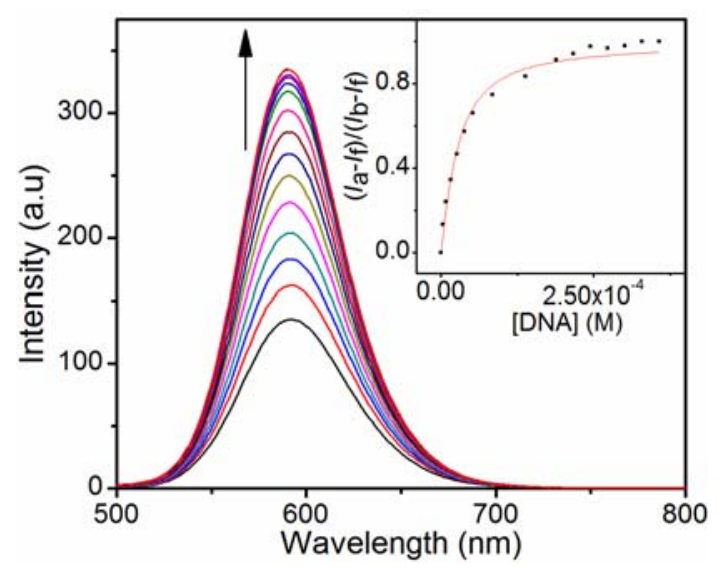

Fig. 2 - Emission spectra of ruthenium complex upon addition of DNA at room temperature. $[\mathrm{Ru}]=5.43 \mu \mathrm{M},[\mathrm{DNA}]=0-328 \mu \mathrm{M}$. Inserted plot: $\left(I_{\mathrm{a}}-I_{\mathrm{f}}\right) /\left(I_{\mathrm{b}}-I_{\mathrm{f}}\right)$ vs. [DNA] for the titration of DNA with complex.

$\left[\mathrm{Fe}(\mathrm{CN})_{6}\right]^{4-}$ decreased drastically. The quenching event corresponds with the Stern-Volmer equation: $I_{0} / I=1+K_{\mathrm{sv}}[\mathrm{Q}]$, in which $I_{0}$ and $I$ are the intensities of the fluorophore in the absence and presence of quencher respectively, [Q] is the concentration of the quencher, and $K_{\mathrm{sv}}$ is a linear Stern-Volmer quenching constant. ${ }^{23,24}$ The $K_{\text {sv }}$ value for the free complex was derived to be 2.16 $\times 10^{3} \mathrm{M}^{-1}$, which is much higher than the $K_{\mathrm{sv}}$ value of $34.45 \mathrm{M}^{-1}$ for the DNA-bound complex. This is because the repulsion between the highly negatively charged $\left[\mathrm{Fe}(\mathrm{CN})_{6}\right]^{4-}$ and the negatively charged phosphate backbone of DNA hinders the access of $\left[\mathrm{Fe}(\mathrm{CN})_{6}\right]^{4-}$ to the DNA-bound complex. $R$, the ratio of a $K_{\mathrm{SV}}$ value in the presence of DNA to that in the absence of DNA, was calculated to be 0.016 . The value is smaller than $0.018,0.027$ and 0.051 that were previously reported by Wang's 
group for three dinuclear DNA intercalator or partial-intercalators, ${ }^{23}$ indicating that the complex is more effectively protected by DNA and there is a strong interaction between the complex and DNA, consistent with the electronic absorption and emission observations.

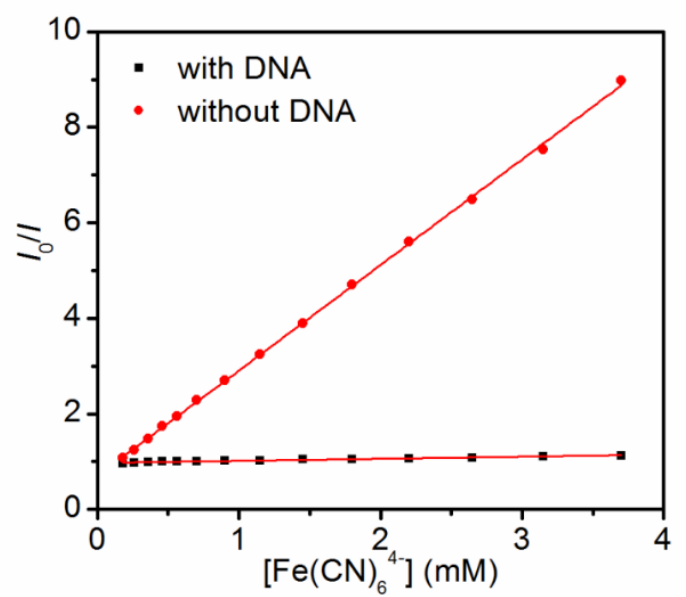

Fig. 3 - Emission quenching of the ruthenium complex with $\left[\mathrm{Fe}(\mathrm{CN})_{6}\right]^{4-}$ in the presence and absence of DNA. $[\mathrm{Ru}]=$ $5.43 \mu \mathrm{M},[\mathrm{DNA}] /[\mathrm{Ru}]=15.0$.

The competitive binding experiments based on the displacement of the intercalating drug EB from DNA can provide further information for the DNA binding properties of the complex. EB is a planar cationic dye, which emits weakly when free in aqueous solution, but exhibits intense fluorescence in the presence of DNA due to its strong intercalation between the adjacent DNA base pairs. ${ }^{25,26}$ If a complex can displace EB from the EB-DNA adduct and interact with DNA, the fluorescence of the EB-DNA solution will be reduced because of the quenching effect of the surrounding water molecules. The degree of fluorescence quenching depends on the DNA binding affinity and binding mode. It is generally acknowledged that large fluorescence quenching should be strong binding strength and intercalative binding mode. Hence, EB displacement technique can give indirect evidence for the interaction nature between complex and DNA. Fig. 4 shows the fluorescence quenching of DNA-bound EB by complex. Upon the addition of the complex, the emission band at $588 \mathrm{~nm}$ exhibited hypochromism up to $89.7 \%$ of the initial fluorescence intensity. The significant decrease in the fluorescence intensity clearly suggests that the EB molecules were displaced from their DNA binding sites by the complex, and the complex interacts with DNA most probably through intercalation. We can also determine from the data in the inset plot of Fig. 4 that $50 \%$ of the EB molecules were displaced from DNA-bound $\mathrm{EB}$ at a concentration ratio of $[\mathrm{Ru}] /[\mathrm{EB}] \approx 0.97$. By assuming a DNA binding constant of EB, $K_{\mathrm{EB}}=1.25 \times 10^{6} \mathrm{M}^{-1},{ }^{27}$ the apparent DNA binding constant $K_{\text {app }}$ of the complex was derived to be $1.29 \times 10^{6} \mathrm{M}^{-1}$ by employing the equation: $K_{\text {app }}=K_{\mathrm{EB}}\{[\mathrm{EB}] /[\mathrm{Ru}]\} 50 \%$, in which $[\mathrm{EB}]_{50 \%}$ and $[\mathrm{Ru}]_{50 \%}$ are the EB and complex concentrations at $50 \%$ EB replacement. The result is close to the $K_{\mathrm{b}}$ values of $1.32 \times 10^{6} \mathrm{M}^{-1}$ and 2.00 $\times 10^{6} \mathrm{M}^{-1}$ obtained from electronic absorption and emission titrations, respectively, which indicates high DNA binding affinity of the complex as well.

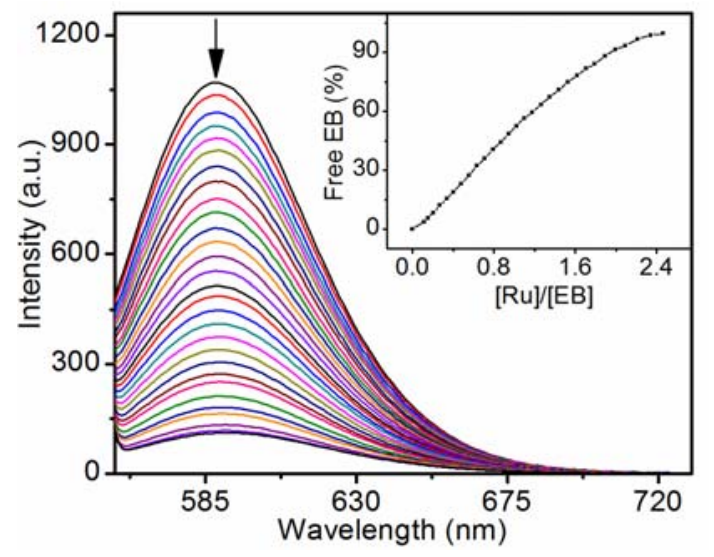

Fig. 4 - Effect of addition of ruthenium complex on the emission intensity of DNA-bound EB. Inset plot: fluorescence intensity of DNA-EB system vs. ratio of $[\mathrm{Ru}] /[\mathrm{EB}]$. $[\mathrm{DNA}]=$ $100 \mu \mathrm{M},[\mathrm{EB}]=5 \mu \mathrm{M}$.

\section{Thermal denaturation of DNA}

The thermal behaviors of DNA in the presence of complexes can provide insight into the stabilization of double-stranded DNA by complexes and give hints on their DNA binding mode. It is well accepted that as temperature increases, the double-stranded DNA gradually dissociates into single strands and generates a hyperchromic effect on the absorption of DNA bases pairs at $260 \mathrm{~nm}$, on account of the smaller of molar absorptivity of the double-stranded DNA than the single-strand form. To identify this transition process, the melting temperature $\left(T_{\mathrm{m}}\right)$, which is defined as the temperature where half of the total base pairs are unbonded, is usually introduced. Generally, a large positive change in the melting temperature occurs when metal complexes bind to DNA by intercalation. Conversely, a low value of $\sim 1-3{ }^{\circ} \mathrm{C}$ suggests groove, electrostatic, or a combination of these 
binding modes. ${ }^{28,29}$ The melting curves of DNA in the absence and presence of complex are presented in Fig. 5. The $T_{\mathrm{m}}{ }^{0}$ value of free DNA was determined as $59.3{ }^{\circ} \mathrm{C}$ under our experimental conditions. With the complex present, the $T_{\mathrm{m}}$ increased successively and reached 60.4, 63.9 and $69.3{ }^{\circ} \mathrm{C}$ at concentration ratios of $[\mathrm{Ru}] /[\mathrm{DNA}]=1$ : $40,1: 20$ and $1: 10$, respectively. The $\Delta T_{\mathrm{m}}$ value of $10.0{ }^{\circ} \mathrm{C}$ at $[\mathrm{Ru}] /[\mathrm{DNA}]=1: 10$ is comparable to 10.4 and $10.5^{\circ} \mathrm{C}$ for $\left[\mathrm{Ru}(\text { bpy })_{2} \text { (pnip) }\right]^{2+}$ \{pnip = 12-[N-(p-phenyl)-1,8-napthalimide]-imidazo[ $\left[4^{\prime}, 5^{\prime}-\right.$ $f][1,10]$ phenanthroline $\}^{30}$ and $\left[\mathrm{Ru}(\mathrm{bpy})_{2}(\mathrm{osip})\right]^{2+}$ $\{$ osip = (E)-2-(4-methoxystyryl)-1H-imidazo[4,5$f][1,10]$ phenanthroline $\},{ }^{31}$ greater than 7.4 and 3.5 ${ }^{\circ} \mathrm{C}$ for $\left[\mathrm{Ru}(\mathrm{bpy})_{2}(\text { pip })\right]^{2+}$ \{pip = 2-phenyl- $1 H$ imidazo[4,5-f][1,10]phenanthroline $\}^{31}$ and a dinuclear complex, ${ }^{23}$ but smaller than 16.5, 14.0, 13.5 and $11.7^{\circ} \mathrm{C}$ for $\left[\mathrm{Ru}(\mathrm{bpy})_{2}(\mathrm{dsip})\right]^{2+}$ \{dsip $=$ (E)-2-(4-dimethyl-aminostyryl)- $1 H$-imidazo[4,5$f][1,10]$ phenanthroline $\},{ }^{31} \quad\left[\mathrm{Ru}(\text { phen })_{2}(\text { pnip })\right]^{2+},{ }^{30}$ $\left[\mathrm{Ru}(\mathrm{bpy})_{2}(\mathrm{nsip})\right]^{2+}\{\mathrm{nsip}=(\mathrm{E})-2-(4-$ nitrostyryl $)-$ $1 H$-imidazo[4,5-f][1,10]phenanthroline $\}^{31}$ and $\left[\mathrm{Ru}(\mathrm{bpy})_{2}(\mathrm{sip})\right]^{2+}\{$ sip $=(\mathrm{E})-2-$ styryl-1H-imidazo[4,5-f][1,10]phenanthroline $\},{ }^{31}$ all of which are testified DNA intercalators. The results reveal that the complex could effectively stabilize the double strands of DNA and the mode of the complex binding to DNA is probably intercalation.

The DNA binding constant $K$ for the complex to DNA at $T_{\mathrm{m}}$ was determined by McGee's eq. $(3):^{32,33}$

$$
1 / T_{\mathrm{m}}^{0}-1 / T_{\mathrm{m}}=\left(R / \Delta H_{\mathrm{m}}\right) \ln (1+K L)^{1 / \mathrm{n}}
$$

where $T_{\mathrm{m}}^{0}$ is the melting point of DNA alone, $T_{\mathrm{m}}$ is the melting temperature in the presence of the complex, $\Delta H_{\mathrm{m}}$ is the enthalpy of DNA melting $\left(\Delta H_{\mathrm{m}}=6.9 \mathrm{kcal} / \mathrm{mol}\right),{ }^{32,33} R$ is the gas constant, $L$ is the free ruthenium complex concentration (approximated by the total complex concentration at $T_{\mathrm{m}}$ ), and $n$ is the binding site size. By using $n=$ 1.79 that derived from the luminescence titration experiment, $K$ was calculated to be $1.34 \times 10^{5} \mathrm{M}^{-1}$ at $69.3{ }^{\circ} \mathrm{C}$, indicating that the complex still displayed certain binding affinity at the melting point of the DNA.

The changes of standard enthalpy $\left(\Delta H_{0}\right)$, standard free energy $\left(\Delta G_{\mathrm{T}}{ }^{0}\right)$ and standard entropy $\left(\Delta S_{0}\right)$ for DNA binding of the complex were determined from the van't Hoff equation, eqs. (4)$(6):^{32,33}$

$$
\begin{gathered}
\left.\ln \left(K_{1} / K_{2}\right)=\left(\Delta H^{0} / R\right)\left(T_{1}-T_{2}\right) / T_{1} T_{2}\right] \\
\Delta G_{\mathrm{T}}{ }^{0}=-R T \ln K \\
\Delta{G_{\mathrm{T}}}^{0}=\Delta H^{0}-T \Delta S^{0}
\end{gathered}
$$

where $K_{1}$ and $K_{2}$ are DNA binding constants of the complex at temperatures $T_{1}$ and $T_{2}$, respectively. By taking $K_{1}=2.00 \times 10^{6} \mathrm{M}^{-1}\left(T_{1}=298.15 \mathrm{~K}\right)$ and $K_{2}=1.34 \times 10^{5} \mathrm{M}^{-1}\left(T_{2}=342.45 \mathrm{~K}\right)$, the $\Delta H^{0}, \Delta G^{0}$ and $\Delta S^{0}$ at $298.15 \mathrm{~K}$ were derived to be -51.80 $\mathrm{KJ} / \mathrm{mol}$, $-35.96 \mathrm{KJ} / \mathrm{mol}$ and $-53.11 \mathrm{~J} / \mathrm{mol} / \mathrm{K}$, respectively. The negative $\Delta G^{0}$ and $\Delta H^{0}$ imply that binding of the complex to DNA is driven both energically and enthalpically at $298.15 \mathrm{~K}$, although the large negative $\Delta S^{0}$ is unfavorable for binding, which is due to the restriction in freedom of the complex upon binding to DNA.

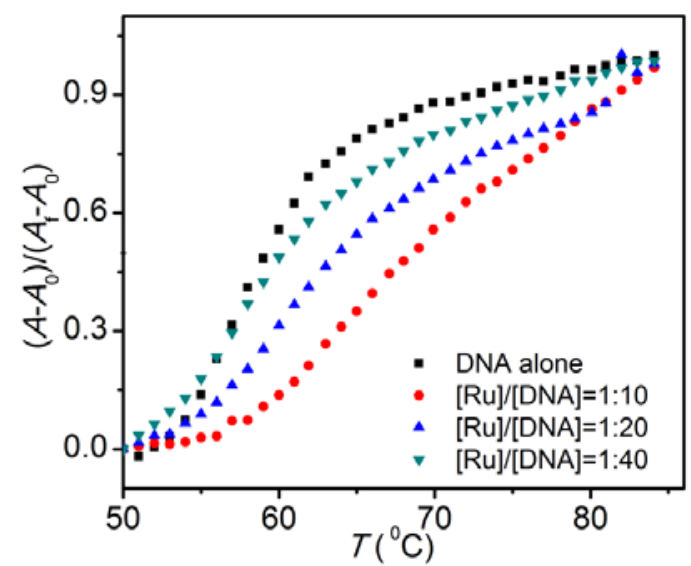

Fig. 5 - Thermal denaturation curves of DNA $(50 \mu \mathrm{M})$ at different ruthenium complex concentrations of $[\mathrm{Ru}] /[\mathrm{DNA}]=$ $1 / 10,1 / 20,1 / 40$, and DNA alone.

\section{Reverse salt effects on DNA binding properties}

At neutral $\mathrm{pH}$, the ruthenium(II) complex possesses a dipositive charge, so the interaction between the complex and nucleic acids should be influenced by the presence of other cations or ionic strength of the solution. As the sensitivity of DNA binding constants to ionic strength is expected to decrease in the order of the binding modes, electrostatic $>$ groove $>$ intercalative, the reverse salt effect experiment is an applicable method to distinguish DNA binding modes. In order to recognize the effects of $\mathrm{NaCl}$ concentrations on DNA binding of the complex both qualitatively and quantitatively, we conducted the electronic absorption titrations in Tris- $\mathrm{HCl}$ buffer solutions with salt concentrations of $0.025,0.050,0.075$ and $0.100 \mathrm{M}$, respectively. According to eq. (1), the $K_{\mathrm{b}}$ values were found to be $2.95 \times 10^{6} \mathrm{M}^{-1}$ for $0.025 \mathrm{M} \mathrm{NaCl}$ (Fig. S1), $1.32 \times 10^{6} \mathrm{M}^{-1}$ for $0.050 \mathrm{M} \mathrm{NaCl}$ (Fig. 6), $7.17 \times 10^{5} \mathrm{M}^{-1}$ for $0.075 \mathrm{M}$ $\mathrm{NaCl}$ (Fig. S2), and $4.18 \times 10^{5} \mathrm{M}^{-1}$ for $0.100 \mathrm{M}$ $\mathrm{NaCl}$ (Fig. S3). It is obvious that the DNA binding constants decreased with increasing salt concentrations, which is ascribed to the 
stoichiometry release of sodium ion following the DNA binding of the complex. This gives a hint that the electrostatic interaction is involved in the DNA binding event.

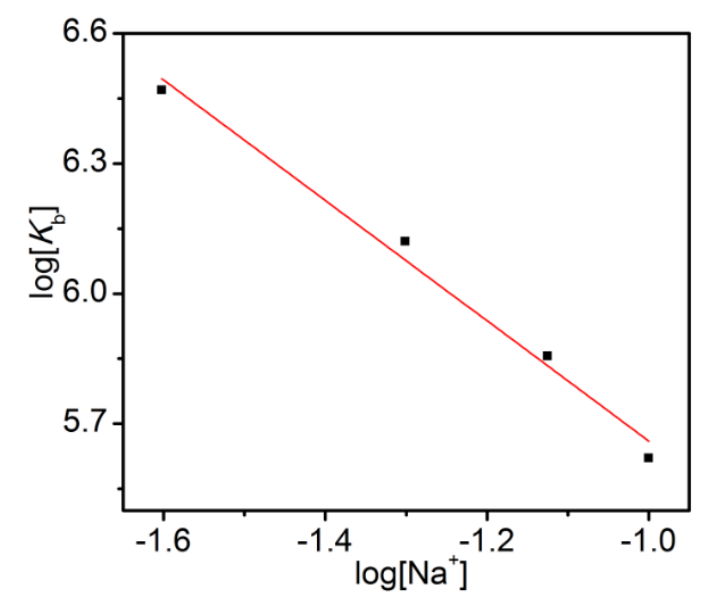

Fig. 6 - Salt dependence of binding constant $\left(K_{\mathrm{b}}\right)$ for binding of ruthenium complex to DNA. The slope of this plot corresponds to $S K$.

The electrostatic and nonelectrostatic contribution to the DNA binding free energy change of the complex could be evaluated with polyelectrolyte theory by using eqs. (7)-(10): ${ }^{34}$

$$
\begin{gathered}
S K=-Z \psi=\delta \log K_{\mathrm{obs}} / \delta \log \left[\mathrm{Na}^{+}\right] \\
\Delta G_{\mathrm{obs}}=-R T \ln K_{\mathrm{obs}} \\
\Delta G_{\mathrm{pe}}=(S K) R T \ln \left[\mathrm{Na}^{+}\right] \\
\Delta G_{\mathrm{t}}=\Delta G_{\mathrm{obs}}-\Delta G_{\mathrm{pe}}
\end{gathered}
$$

where $Z$ is the charge on the ruthenium complex, $\psi$ is the fraction of counterions associated with each DNA phosphate $(\psi=0.88$ for double-stranded Bform DNA), $\Delta G_{\text {obs }}$ is the binding free energy change, $\Delta G_{\mathrm{pe}}$ and $\Delta G_{\mathrm{t}}$ are electrostatic and nonelectrostatic portions of the binding free energy change, respectively. By linear fitting of $\log K_{\mathrm{b}}$ versus $\log \left[\mathrm{Na}^{+}\right]$, a $S K$ value of -1.39 was obtained and a charge $Z$ of 1.58 was yielded, which is less than two positive charges carried by the ruthenium(II) complex. At $0.050 \mathrm{M} \mathrm{NaCl}, \Delta G_{\mathrm{pe}}$ and $\Delta G_{\mathrm{t}}$ were derived to be -10.31 and $-24.62 \mathrm{~kJ} / \mathrm{mol}$, accounting for $29.5 \%$ and $70.5 \%$ of the overall free energy change, respectively. The high nonelectrostatic free energy contribution to $\Delta G_{\text {obs }}$ observed $(70.5 \%)$ falls within the corresponding values of $63 \%-85 \%$ previously reported for proven DNA intercalators of EB $(85 \%){ }^{35}$ daynomycin $(84.4 \%),{ }^{35} \Delta$-[Ru(phen $)_{2}$ $(\mathrm{dppz})]^{2+}(63 \%)^{36}$ and $\left[\mathrm{Ru}(\mathrm{bpy})_{2} \text { (Htip) }\right]^{2+}\{$ Htip $=$ 2-(thiophen-2-yl)- $1 H$-imidazo[4,5-f][1,10]phenanthroline $3(73 \%),{ }^{34}$ while much greater than $32 \%-$
$57 \%$ for groove binders or electrostatic binders of $\Delta-\left[\mathrm{Ru}(\text { phen })_{3}\right]^{2+}(57 \%),{ }^{37}\left[\mathrm{Ru}(\text { phen })_{2}(\mathrm{cdpq})\right]^{+}\{\mathrm{cdpq}=$ 2-carboxyldipyrido[3,2-f:2',3'-h]quinoxaline $\}(55 \%),{ }^{38}$ $\left[\mathrm{Ru}_{2}(\text { bpy })_{4}(\mathrm{Mebpy})\left(\mathrm{CH}_{2}\right)_{7}(\mathrm{Mebpy})\right]^{4+}$ Mebpy $=4-$ methyl-2,2'-bipyridine $\} \quad(32 \%)^{39}$ and $\left[\mathrm{Ru}_{2}(\mathrm{bpy})_{4}\right.$

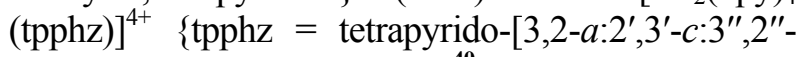
$\left.h: 2^{\prime \prime \prime}, 3^{\prime \prime \prime}-j\right]$ phenazine $\} \quad(39 \%),{ }^{40}$ strongly supporting that the complex is a DNA intercalator.

\section{DNA viscosity measurements}

The most definitive method for assignment of binding modes of complexes to DNA is viscosity measurements in the absence of crystallographic data or NMR spectra. ${ }^{28,41}$ It is well known that classical intercalation of a ligand into DNA results in lengthening the DNA helix and concomitantly the increase of DNA viscosity, as the base pairs of DNA are detached to accommodate the binding ligand. However, in the partial or non-classical intercalative mode of binding, the ligand could bend (or kink) the DNA helix, leading to the decrease of effective length and viscosity of DNA. In contrast, an electrostatic or groove binding mode has little effects on the DNA viscosity. ${ }^{28,41} \mathrm{As}$ shown in Fig. 7, the specific relative viscosity of the DNA was measured by adding increasing amounts of complex and a known DNA intercalator EB for comparison purpose. It is clear that both the proven DNA intercalator of EB and the present complex increased the viscosity of DNA significantly. This type of behavior suggests that the complex bound to DNA via an intercalation mode, similarly to the reported intercalative binding mode of [Ru(bpy $)_{2}$ (depip)] $\left(\mathrm{ClO}_{4}\right)_{2}{ }^{4}, \quad\left[\mathrm{Ru}(\text { phen })_{2}(\right.$ depip $\left.)\right]\left(\mathrm{ClO}_{4}\right)_{2}{ }^{4}, \quad\left[\mathrm{Ru}(\mathrm{dmb})_{2}\right.$ (depip) $]\left(\mathrm{ClO}_{4}\right)_{2},{ }^{4}\left[\mathrm{Ru}(\mathrm{bpy})_{2}(\mathrm{BTCP})\right]\left(\mathrm{PF}_{6}\right)_{2} \quad$ (BTCP $=2$-(bicyclo[2.2.1]hept-5-en-2-yl)-1 $H$-imidazo[4,5-f] $[1,10]$ phenanthroline $\},{ }^{22} \quad\left[\mathrm{Ru}(\mathrm{dmb})_{2} \quad(\mathrm{BTCP})\right]$ $\left(\mathrm{PF}_{6}\right)_{2},{ }^{22}\left[\mathrm{Ru}(\mathrm{ttbpy})_{2}(\mathrm{BTCP})\right]\left(\mathrm{PF}_{6}\right)_{2} \quad\{$ ttbpy $=$ ditertairybutyl-2,2'-bipyridine $\}, \quad\left[\mathrm{Ru}(\text { phen })_{2}\right.$ (BTCP)] $\left(\mathrm{PF}_{6}\right)_{2},{ }^{22}\left[\mathrm{Ru}(\mathrm{bpy})_{2}(\mathrm{CIIP})\right]\left(\mathrm{ClO}_{4}\right)_{2},{ }^{17}\left[\mathrm{Ru}(\mathrm{dmb})_{2}\right.$ (CIIP) $]\left(\mathrm{ClO}_{4}\right)_{2},{ }^{17}\left[\mathrm{Ru}(\mathrm{dmb})_{2}(\mathrm{BOPIP})\right]\left(\mathrm{ClO}_{4}\right)_{2}{ }^{18}$ and $\left[\mathrm{Ru}(\mathrm{Hdpa})_{2}(\mathrm{BOPIP})\right]\left(\mathrm{ClO}_{4}\right)_{2} \quad\{\mathrm{Hdpa}=$ $2,2^{\prime}$ dipyridylamine $\},{ }^{18}$ and in good agreement with the results of aforementioned optical spectroscopy studies.

Notably, the complex usually binds to DNA more tightly in an intercalation mode than in other modes. However, the complex combined with G-quadruplex through an "external stacking" model other than intercalation as proved in our previous studies, but it exhibited higher binding constant $\left(K_{\mathrm{b}}=2.56 \times 10^{6} \mathrm{M}^{-1}\right)$ and emission 
enhancement factor $\left(I / I_{0}=3.1\right.$ and 4.2 in Tris-NaCl and Tris- $\mathrm{KCl}$ buffer, respectively) for Gquadruplex than those for ct-DNA. ${ }^{42}$ This may be due to the bulky structure of G-quadruplex which is composed of more negative phosphate backbone, leading to stronger electronic interaction between the complex and G-quadruplex DNA.

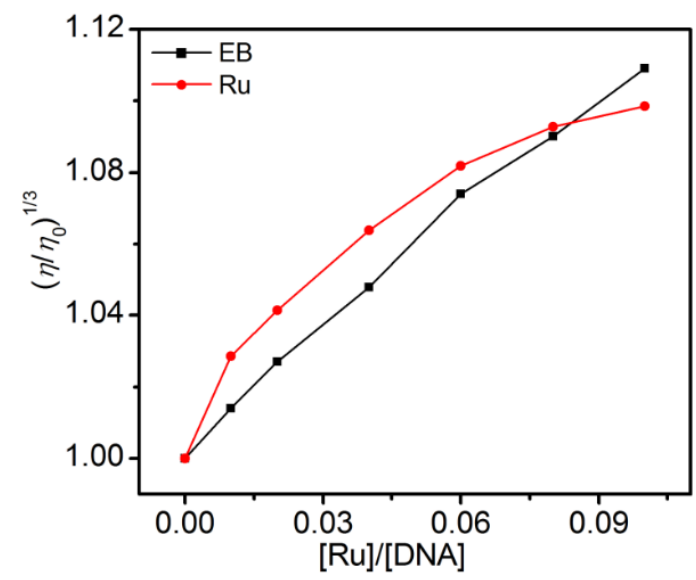

Fig. 7 - Effect of increasing amounts of ruthenium complex and $\mathrm{EB}$ on the relative viscosity of DNA at $32.0 \pm 0.1^{\circ} \mathrm{C}$.

\section{Photocleavage of DNA}

The cleavage reactions on plasmid DNA induced by complex were monitored by agarose gel electrophoresis. When circular plasmid DNA is subjected to electrophoresis, relatively fast migration is observed for the intact supercoiled form (Form I). If scission occurs on one strand (nicking), the supercoil relax to generate a slowermoving open circular form (Form II). If both strands are cleaved, a linear form (Form III) is generated that migrates between Form I and II. ${ }^{43}$ As seen in Fig. 8, lane 1 is the pure DNA alone and lane 2 is the DNA with $24 \mu \mathrm{M}$ of complex present in the dark, both of which resulted in little or no DNA cleavage. In contrast, upon irradiarion at $365 \mathrm{~nm}$ for only $15 \mathrm{~min}$, the Form II of DNA increased continuously, while Form I diminished gradually, by increasing the concentrations of the complex. When the concentration of complex reached $24 \mu \mathrm{M}$, Form I was almost completely converted to Form II. The results indicate that the complex possess strong activities to photocleave pBR322 DNA, with the cleavage ability higher than that of $\left[\mathrm{Ru}(\text { bpy })_{2}(\right.$ depip $\left.)\right]\left(\mathrm{ClO}_{4}\right)_{2},{ }^{4}$ $\left[\mathrm{Ru}(\text { phen })_{2}(\right.$ depip $\left.)\right]\left(\mathrm{ClO}_{4}\right)_{2}{ }^{4}$

$\left[\mathrm{Ru}(\mathrm{dmb})_{2}(\mathrm{depip})\right]\left(\mathrm{ClO}_{4}\right)_{2},{ }^{4}$

$\left[\mathrm{Ru}(\mathrm{bpy})_{2}(\mathrm{CIIP})\right]\left(\mathrm{ClO}_{4}\right)_{2},{ }^{17}$

$\left[\mathrm{Ru}(\mathrm{dmb})_{2}(\mathrm{CIIP})\right]\left(\mathrm{ClO}_{4}\right)_{2},{ }^{17}$
$\left[\mathrm{Ru}(\mathrm{dmb})_{2}(\mathrm{BOPIP})\right]\left(\mathrm{ClO}_{4}\right)_{2}{ }^{18}$ $\left[\mathrm{Ru}(\mathrm{Hdpa})_{2}(\mathrm{BOPIP})\right]\left(\mathrm{ClO}_{4}\right)_{2}{ }^{18}$

and

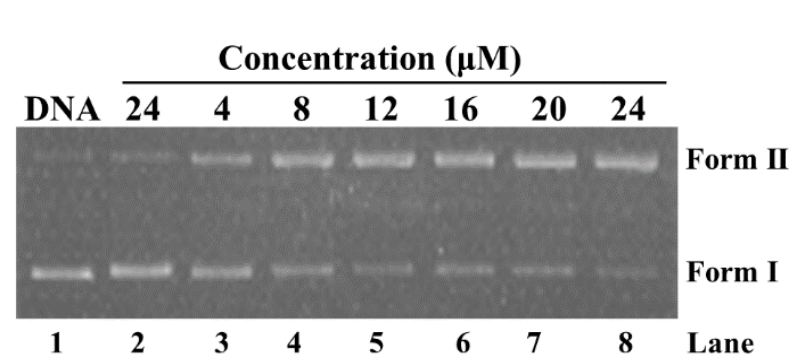

Fig. 8 - Photocleavage of pBR322 DNA incubating with the ruthenium complex, irradiation at $365 \mathrm{~nm}$ for $15 \mathrm{~min}$ or in dark. Lane 1, DNA alone; lane 2, DNA with the $24 \mu \mathrm{M}$ ruthenium complex without irradiation; lanes 3-8, at 4, 8, 12, 16,20 and $24 \mu \mathrm{M}$ ruthenium complex, respectively.

\section{Density functional theory (DFT) calculations}

It was reported that the DNA binding affinity of a drug molecule relies on the following three factors: $:^{21,34,44,45}(1)$ the planarity and planarity area of the intercalative moiety of the drug. Usually, the excellent planarity and the larger planarity area of the intercalative ligand would result in stronger DNA binding. (2) the charge carried by the complex. The more positive charge carried by the drug would make more contributions to the electrostatic interaction between the positively charge drug and negatively charged DNA, and thus enhancing the DNA binding affinity. (3) the energies of the lowest unoccupied molecular orbital (LUMO) and/or some virtual orbitals near LUMO $(\mathrm{LUMO}+\mathrm{n})$ that are mainly localized on the intercalating moiety. Since the intercalating ligand and the DNA base pairs behave as electron acceptor and electron donors, respectively, in the process of $\pi-\pi$ stacking interactions, the lower energies of LUMOs of the complex are advantageous for the intercalating ligand to accept electrons donated by the base pairs of DNA, contributing to greater DNA binding affinity. The optimized structure and contour plots of some frontier molecular orbitals of the complex were shown in Fig. 9. According to the previous theoretical studies regarding the complex done by us, the dihedral angles of N1-C2-C3-N4 and N4C5-C6-O7 in Fig. 9 (a) are nearly $180^{\circ},{ }^{42}$ indicating that the hydroxyquinoline and the ip moieties on the complex are almost coplanar, and the plane area of the main ligand ipq is larger as compared to ligand ip. Therefore, the ligand ipq could insert into the base pairs of DNA in the process of DNA binding. In addition, the 
populations and energies of some frontier molecular orbitals for the complex is different from the parent analogue $\left[\mathrm{Ru}(\mathrm{bpy})_{2}(\mathrm{ip})\right]^{2+}$. In terms of DFT calculations on $\left[\mathrm{Ru}(\mathrm{bpy})_{2}(\mathrm{ip})\right]^{2+}$ reported in the literature, ${ }^{21,46}$ the electron densities of HOMO, HOMO-1 and HOMO-2 are mainly localized on $\mathrm{Ru}$, and $\mathrm{LUMO}+2$ and $\mathrm{LUMO}+3$ are dominantly distributed on the main ligand ip. Whereas, for the present complex in Fig. 9 (b), the electron densities of HOMO-2 are directly to $\mathrm{Ru}$, and $\mathrm{LUMO}+8$ are contributed on the whole main ligand ipq, with those of $\mathrm{LUMO}+2$ being populated on the phen part of ipq, and LUMO+3 being distributed on the ip part of ipq. It is worthnoting that the energies of LUMO+2 (-6.9645 eV), LUMO+3 (-6.5414 eV) and LUMO+8 $(-5.5205 \mathrm{eV})$ of the complex are much higher than the calculated energies $(-2.08$ $1.27 \mathrm{eV}$ ) of HOMO and 6 occupied molecular orbitals near HOMO for DNA base pairs CG/GC stacking, ${ }^{45,47}$ which is in favor of electron flow from HOMOs of DNA to LUMO+2, $\mathrm{LUMO}+3$ and LUMO +8 of the complex, suggesting that the interaction between the complex and the base pairs of DNA should be strong $\pi-\pi$ stacking. However, the energies of $\mathrm{LUMO}+2, \mathrm{LUMO}+3$ and $\mathrm{LUMO}+8$ of the complex are higher than those of $\mathrm{LUMO}+2$ $(-7.4011 \mathrm{eV})$ and LUMO+3 (-7.0202 eV) for $\left[\mathrm{Ru}(\mathrm{bpy})_{2}(\mathrm{ip})\right]^{2+}$, indicating that the LUMOs for the complex are less favorable for DNA binding than those of $\left[\mathrm{Ru}(\mathrm{bpy})_{2}(\mathrm{ip})\right]^{2+}$, in contrast to experimentally observed DNA binding affinity order. This led us to draw a conclusion that that the larger plane area of ipq than ip makes a dominant contribution on experimentally observed greater DNA binding affinity of the complex than that of $\left[\mathrm{Ru}(\mathrm{bpy})_{2}(\mathrm{ip})\right]^{2+}$.

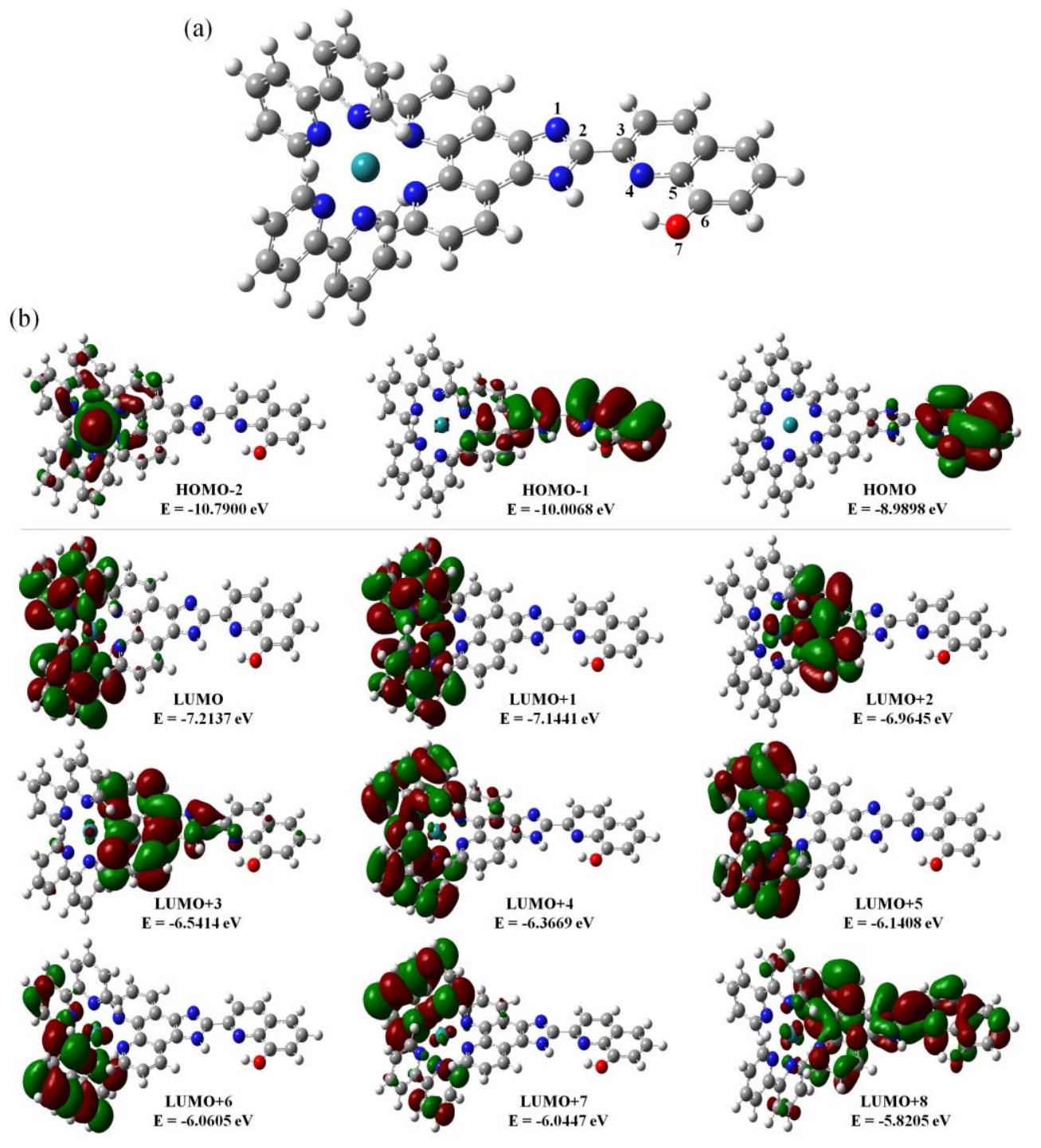

Fig. 9 - (a) The optimized structure of ruthenium complex.

(b) Contour plots of some related frontier molecular orbitals of ruthenium complex. 


\section{EXPERIMENTAL SECTION}

\section{Materials and methods}

The compound $\left[\mathrm{Ru}(\mathrm{bpy})_{2}(\mathrm{ipq})\right]\left(\mathrm{ClO}_{4}\right)_{2}$ was prepared according to the literature method, ${ }^{42}$ and the synthetic details and synthetic route are given in the supporting information. It was characterized by ${ }^{1} \mathrm{H}$ NMR and ${ }^{13} \mathrm{C}$ NMR, and the data were found to be identical to those reported in the literature. ${ }^{42}$ The molecular structure of the complex is shown in Scheme 1. The calf thymus DNA (ct-DNA) was obtained from Shanghai Sangon Biological Engineering Technology \& Services (Shanghai, China) and used without further purification (longterm storage at $\left.-20{ }^{\circ} \mathrm{C}\right)$. Several buffers of A ( $5 \mathrm{mM}$ Tris- $\mathrm{HCl}$, $50 \mathrm{mM} \mathrm{NaCl}, \mathrm{pH}=7.10 \pm 0.02$ ) was used for absorption titration, luminescence titration, steady-state emission quenching, ethidium bromide (EB) competition and viscosity measurements; $\mathrm{B}$ (1.5 mM Na $2 \mathrm{HPO}_{4}, 0.5 \mathrm{mM} \mathrm{NaH} \mathrm{PO}_{4}, 0.25 \mathrm{mM} \mathrm{Na} 2$ EDTA, $\mathrm{pH}=6.28 \pm 0.02)$ was used for thermal denaturation experiments; C $(50 \mathrm{mM}$ Tris- $\mathrm{HCl}, 18 \mathrm{mM} \mathrm{NaCl}, \mathrm{pH}=7.2)$ and D (TBE, $89 \mathrm{mM}$ Tris, $2 \mathrm{mM}$ EDTA, $88 \mathrm{mM}$ boracic acid, $\mathrm{pH}=8.3$ ) were used for DNA photocleavage experiments. All solutions involving the DNA experiments were prepared by thrice distilled water. A solution of ct-DNA in the buffer A (centrifuged for 20 minutes and incubated at $4{ }^{\circ} \mathrm{C}$ overnight) gave a ratio of UV absorbance at 260 and $280 \mathrm{~nm}$ of 1.8 $1.9: 1$, indicating that the DNA was free from protein. The DNA concentration per nucleotide was determined by absorption spectroscopy using the molar absorption coefficient $\left(6600 \mathrm{M}^{-1} \mathrm{~cm}^{-1}\right)$ at $260 \mathrm{~nm}^{5}$

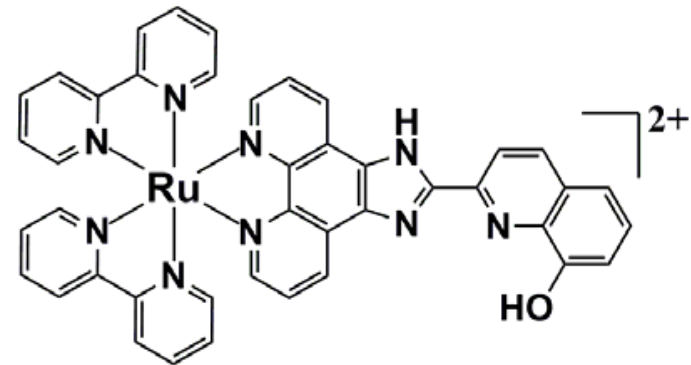

Scheme 1 - Molecular structure of $\left[\mathrm{Ru}(\mathrm{bpy})_{2}(\mathrm{ipq})\right]\left(\mathrm{ClO}_{4}\right)_{2}$.

\section{DNA binding studies}

Electronic absorption spectroscopy: UV-vis absorption spectra were recorded on a Shimadzu UV-3600 spectrophotometer in order to investigate the possible binding mode and binding constant $\left(K_{\mathrm{b}}\right)$ of the complex to DNA. Absorption studies were performed in buffer A with fixed compound concentrations while varying the DNA concentration within. Ru-DNA solutions were allowed to incubate for $5 \mathrm{~min}$ before the absorption spectra were recorded until the absorbance did not change any more. The intrinsic binding constant $K_{\mathrm{b}}$, of the ruthenium complex bound to DNA was calculated from eq. (1): ${ }^{19}$

$\left.\left(\varepsilon_{\mathrm{a}}-\varepsilon_{\mathrm{f}}\right) /\left(\varepsilon_{\mathrm{b}}-\varepsilon_{\mathrm{f}}\right)=\left(b-\left(b^{2}-2 K_{\mathrm{b}}^{2} C_{\mathrm{t}}[\mathrm{DNA}]\right) / s\right)^{1 / 2}\right) /\left(2 K_{\mathrm{b}} C_{\mathrm{t}}\right)$

$b=1+K_{\mathrm{b}} C_{\mathrm{t}}+K_{\mathrm{b}}[\mathrm{DNA}] / 2 s$

where [DNA] is the concentration of DNA in base pairs; the apparent absorption coefficients $\varepsilon_{\mathrm{a}}, \varepsilon_{\mathrm{b}}$ and $\varepsilon_{\mathrm{f}}$ correspond to the extinction coefficients at a given DNA concentration, the free complex in solution and the complex that is fully bound to DNA, respectively; $C_{\mathrm{t}}$ is the total metal complex concentration; $s$ is the binding site size.
Luminescence spectroscopy: The emission spectra were measured on an Edinburgh Instruments FS5 spectrofluorophotometer. The luminescence titrations were performed in buffer A, for which the concentration of the ruthenium complex was fixed and increasing concentrations of the stock solution of DNA was added. The steady-state quenching experiments were carried out by adding aliquots of $\mathrm{K}_{4}\left[\mathrm{Fe}(\mathrm{CN})_{6}\right]$ stock solution to the sample solutions containing DNA and ruthenium complex in buffer A. The experiments of DNA competitive binding with EB were conducted in buffer A by keeping $[\mathrm{DNA}] /[\mathrm{EB}]=5$ and varying the concentrations of ruthenium complex. The fluorescence spectra of EB were measured using excitation wavelength at $537 \mathrm{~nm}$. All solutions were allowed to equilibrate thermally for $5 \mathrm{~min}$ before measurements were made. From the emission titration data the $K_{\mathrm{b}}$ value of the ruthenium complex bound to DNA was calculated from eq. (2): ${ }^{27}$

$\left.\left(I_{\mathrm{a}}-I_{\mathrm{f}}\right) /\left(I_{\mathrm{b}}-I_{\mathrm{f}}\right)=\left(b-\left(b^{2}-2 K_{\mathrm{b}}^{2} C_{\mathrm{t}}[\mathrm{DNA}]\right) / s\right)^{1 / 2}\right) /\left(2 K_{\mathrm{b}} C_{\mathrm{t}}\right)$

$b=1+K_{\mathrm{b}} C_{\mathrm{t}}+K_{\mathrm{b}}[\mathrm{DNA}] / 2 s$

where [DNA] is the concentration of DNA in base pairs; $I_{\mathrm{a}}, I_{\mathrm{b}}$ and $I_{\mathrm{f}}$ corresponds to the fluorescent intensity of the complex at a given DNA concentration, the fluorescent intensity for the free complex and DNA-bound complex when saturated respectively; $C_{\mathrm{t}}$ is the total metal complex concentration; $s$ is the binding site size.

DNA thermal denaturation: The thermal denaturation studies were performed on Shimadzu UV-3600 spectrophotometer equipped with a temperature-controlling programmer $\left( \pm 0.1^{\circ} \mathrm{C}\right)$. Solutions of DNA molecule both in the absence and presence of the ruthenium complex were prepared in buffer B. All solutions were needed to incubate for an hour before being measured. The temperature of the solution was increased from 50 to $85^{\circ} \mathrm{C}$ at an increasing rate of $1{ }^{\circ} \mathrm{C} / \mathrm{min}$, and the absorbance at $260 \mathrm{~nm}$ was monitored every $1{ }^{\circ} \mathrm{C}$. The $T_{\mathrm{m}}$ values were determined from plots of $\left(A-A_{0}\right) /\left(A_{\mathrm{f}}-A_{0}\right)$ versus temperature, where $A_{\mathrm{f}}, A_{0}, A$ are the final, initial and observed absorbance at $260 \mathrm{~nm}$, respectively.

Viscosity measurements: Viscosity measurements were carried out using an Ubbelodhe viscometer maintained at a constant temperature at $32.0 \pm 0.1^{\circ} \mathrm{C}$ in a thermostatic bath. DNA samples approximately 200 base pairs in average length were prepared by sonication to minimize complexities arising from DNA flexibility. Flow time was measured with a digital stopwatch, and each sample was measured three times and an average flow time was calculated. Relative viscosities for DNA in the presence and absence of ruthenium complex were calculated from the relation $\eta=\left(t-t_{0}\right)$, where $t$ is the observed flow time of the DNA-containing solution and $t_{0}$ is the flow time of buffer alone. Data were presented as $\left(\eta / \eta_{0}\right)^{1 / 3}$ versus the $[\mathrm{Ru}] /[\mathrm{DNA}]$, where $\eta$ is the viscosity of DNA in the presence of complex and $\eta_{0}$ is the viscosity of DNA alone. ${ }^{28}$

\section{DNA cleavage experiments}

The photoinduced DNA cleavage by ruthenium complex was examined by gel electrophoresis. Supercoiled pBR322 DNA $(0.2 \mu \mathrm{g})$ was treated with the ruthenium complex in buffer $\mathrm{C}$ in the dark for $1 \mathrm{~h}$, and then the resultant solution was irradiated at $365 \mathrm{~nm}$ for $15 \mathrm{~min}$ using a UV lamp (Analytik Jena US). The samples were analyzed by electrophoresis for $1 \mathrm{~h}$ at $100 \mathrm{~V}$ on a $1 \%$ agarose gel in TBE buffer. The gel was stained with $1 \mu \mathrm{g} / \mathrm{mL}$ EB and photographed under UV light. 


\section{Density Functional Theory (DFT) Calculations}

The theoretical computations for ruthenium complex were performed by applying the DFT method. All of the calculations were performed with the Gaussian 09 quantum chemistry program package. Full geometry optimization computations were performed by applying the density functional B3LYP method with a mixed basis set, in which LanL2DZ was used for Ru and 6-31G* was applied for the other atoms, and assuming the singlet state for the ground state of the complex. To vividly depict the detail of the frontier molecular orbital interactions, the stereographs of some related frontier molecular orbitals of the complex were drawn with Gaussview based on the computational results.

\section{CONCLUSION}

In summary, a ruthenium(II) complex [Ru(bpy) (ipq) $]\left(\mathrm{ClO}_{4}\right)_{2}$ has been synthesized and characterized. The results demonstrated that the DNA binding properties of the complex were significantly improved by appending the hydroxyquinoline group to the parent complex $\left[\mathrm{Ru}(\mathrm{bpy})_{2}(\mathrm{ip})\right]\left(\mathrm{ClO}_{4}\right)_{2}$. As evidenced by spectroscopic techniques and DNA viscosity data, complex $\left[\mathrm{Ru}(\mathrm{bpy})_{2}(\mathrm{ipq})\right]\left(\mathrm{ClO}_{4}\right)_{2}$ bound to DNA through a mode of classic intercalation with DNA binding constant on the order of magnitude of $10^{6} \mathrm{M}^{-1}$, which is two order of magnitude greater than a $K_{\mathrm{b}}$ value previously reported for $\left[\mathrm{Ru}(\mathrm{bpy})_{2}(\mathrm{ip})\right]\left(\mathrm{ClO}_{4}\right)_{2}$. The density functional theory calculations showed that the enhanced DNA binding affinity of the complex relative to that of the hydroxyquinoline-free parent complex $\left[\mathrm{Ru}(\mathrm{bpy})_{2}\right.$ (ip) $]\left(\mathrm{ClO}_{4}\right)_{2}$ is due to the larger conjugation plane of the main ligand of ipq rather than the electronic factors of the populations and energies of LUMOs localized on ipq and ip. When irradiated at $365 \mathrm{~nm},\left[\mathrm{Ru}(\mathrm{bpy})_{2}(\mathrm{ipq})\right]\left(\mathrm{ClO}_{4}\right)_{2}$ was found to be an efficient pBR322 DNA photocleaver with cleavage efficiency greater than many analogous ip moiety-containing complexes. This work would provide fundamental experimental data for the development of potential metal based anticancer agents.

Acknowledgements. The authors thank the National Natural Science Foundation (No. 21401038), Natural Science Foundation of Hebei Province (No. B2016201122), the Science and Technology Research and Development Plan Project of Baoding City (No.14ZF009), the Science and Technology Development Plan Project in Tai'an City (No. 2015GX2048), and the Scientific Research Foundation of Taishan University (No. Y-01-2014017).

\section{REFERENCES}

1. V. Brabec and J. Kasparkova, Coord. Chem. Rev., 2018, 376, 75-94.
2. V. Brabec, O. Hrabina and J. Kasparkova, Coord. Chem. Rev., 2017, 351, 2-31.

3. S. Ghosh, Bioorg. Chem., 2019, 88, 102925.

4. R. K. Vuradi, K. Dandu, P. K. Yata, M. V. Rani, R. R. Mallepally, N. Chintakuntla, R. Ch, S. S. Thakur, C. M. Rao and S. Satyanarayana, New J. Chem., 2018, 42, 846-859.

5. A. M. Sarhan, S. A. Elsayed, M. M. Mashaly and A. M. ElHendawy, Appl. Organometal. Chem., 2019, 33, e4655.

6. G. Sava, K. Clerici, I. Capozzi, M. Cocchietto, R. Gagliardi, E. Alessio, G. Mestroni and A. Perbellini, Anti-Cancer Drugs, 1999, 10, 129-138.

7. G. Sava, R. Gagliardi, A. Bergamo, E. Alessio and G. Mestroni, Anticancer Res., 1999, 19, 969-972.

8. I. Bratsos, S. Jedner, T. Gianferrara and E. Alessio, Met. Med., 2007, 61, 692-697.

9. X. Meng, M. L. Leyva, M. Jenny, I. Gross, S. Benosman, B. Fricker, S. Harlepp, P. Hébraud, A. Boos, P. Wlosik, P. Bischoff, C. Sirlin, M. Pfeffer, J. P. Loeffler and C. Gaiddon, Cancer Res., 2009, 69, 5458-5466.

10. C. Scolaro, A. Bergamo, L. Brescacin, R. Delfino, M. Cocchietto, G. Laurenczy, T. J. Geldbach, G. Sava and P. J. Dyson, J. Med. Chem., 2005, 48, 4161-4171.

11. P. Nowak-Sliwinska, J. R. van Beijnum, A. Casini, A. A. Nazarov, G. Wagnières, H. van den Bergh, P. J. Dyson and A. W. Griffioen, J. Med. Chem., 2011, 54, 3895-3902.

12. S. Syam, S. I. Abdelwahab, M. A. Al-Mamary and S. Mohan, Molecules, 2012, 17, 6179-6195.

13. G. Y. Li, L. L. Sun, L. N. Ji and H. Chao, Dalton. Trans., 2016, 45, 13261-13276.

14. C. S. Burke, A. Byrne and T. E. Keyes, Angew. Chem. Int. Ed., 2018, 57, 12420-12424.

15. J. D. Knoll and C. Turro, Coord. Chem. Rev., 2015, 282$283,110-126$.

16. B. Yu, T. W. Rees, J. W. Liang, C. Z. Jin, Y. Chen, L. N. Ji and H. Chao, Dalton Trans., 2019, 48, 3914-3921.

17. C. Ravi, R. K. Vuradi, S. Avudoddi, P. K. Yata, V. R. Putta, G. Srinivas, R. Merugu and S. Satyanarayana, Nucleos. Nucleot. Nucl., 2019, 1-19.

18. S. Gopu, V. R. Kumar, K. L. Reddy, P. V. Reddy and S. Sirasani, Nucleos. Nucleot. Nucl., 2019, 38, 349-373.

19. N. Chitrapriya, Y. J. Jang, S. K. Kim and H. Lee, J. Inorg. Biochem., 2011, 105, 1569-1575.

20. B. Y. Sun, H. M. Southam, J. A. Butler, R. K. Poole, A. Burgun, A. Tarzia, F. R. Keene and J. G. Collins, Dalton Trans., 2018, 47, 2422-2434.

21. K. C. Zheng, H. Deng, X. W. Liu, H. Li, H. Chao and L. N. Ji, J. Mol. Struct. (Theochem), 2004, 682, 225-233.

22. H. L. Huang, B. Tang, Q. Y. Yi, D. Wan, L. L. Yang and Y. J. Liu, Transit. Metal Chem., 2019, 44, 11-24.

23. P. Liu, B. Y. Wu, J. Liu, Y. C. Dai, Y. J. Wang and K. Z. Wang, Inorg. Chem., 2016, 55, 1412-1422.

24. Y. P. Kumar, C. S. Devi, A. Srishailam, N. Deepika, V. R. Kumar, P. V. Reddy, K. Nagasuryaprasad, S. S. Singh, P. Nagababu and S. Satyanarayana, J. Fluoresc., 2016, 26, 2119-2132.

25. M. Ganeshpandian, M. Palaniandavar, A. Muruganantham, S. K. Ghosh, A. Riyasdeen and M. A. Akbarsha, Appl. Organometal. Chem., 2018, 32, e4154.

26. V. Muthuraj and M. Umadevi, J. Mol. Struct., 2018, 1157, 201-209.

27. S. Mardanya, S. Karmakar, D. Mondal and S. Baitalik, Inorg. Chem., 2016, 55, 3475-3489.

28. C. S. Devi, B. Thulasiram, S. Satyanarayana and P. Nagababu, J. Fluoresc., 2017, 27, 2119-2130. 
29. F. A. Beckford, M. B. Niece, B. P. Lassiter, S. J. Beebe and A. A. Holder, J. Biol. Inorg. Chem., 2018, 23, 1205 1217

30. Y. M. Sun, J. Li, H. Zhao and L. F. Tan, J. Inorg. Biochem., 2016, 163, 88-94.

31. G. L. Ma, X. D. Bi, F. Gao, Z. Feng, D. C. Zhao, F. J. Lin, R. Yan, D. D. Liu, P. Liu, J. B. Chen and H. B. Zhang, J. Inorg. Biochem., 2018, 185, 1-9.

32. S. Satyanarayana, J. C. Dabrowiak and J. B. Chaires, Biochemistry, 1993, 32, 2573-2584.

33. Y. M. Chen, Y. J. Liu, Q. Li and K. Z. Wang, J. Inorg. Biochem., 2009, 103, 1395-1404.

34. Z. S. Li, H. X. Yang, A. G. Zhang, H. Luo and K. Z. Wang, Inorg. Chim. Acta, 2011, 370, 132-140.

35. Mudasir, K. Wijaya, E. T. Wahyuni, N. Yoshioka and H. Inoue, Biophys. Chem., 2006, 121, 44-50.

36. I. Haq, P. Lincoln, D. Suh, B. Norden, B. Z. Chowdhry and J. B. Chaires, J. Am. Chem. Soc., 1995, 117, 4788-4796.

37. S. Satyanarayana, J. C. Dabrowiak and J. B. Chaires, Biochemistry, 1992, 31, 9319-9324.

38. A. G. Zhang, Y. Z. Zhang, Z. M. Duan and K. Z. Wang, Inorg. Chem., 2011, 50, 6425-6436.
39. F. M. O'Reilly and J. M. Kelly, J. Phys. Chem. B, 2000, 104, 7206-7213.

40. D. A. Lutterman, A. Chouai, Y. Liu, Y. Sun, C. D. Stewart, K. R. Dunbar and C. Turro, J. Am. Chem. Soc., 2008, 130, 1163-1170.

41. M. Mariappana, A. Ramasamya, P. A. Prasantha, V. Anbazhaganb, R. Senthilnathanb and A. Jothi, $J$. Photoch. Photobio. A, 2018, 356, 617-626.

42. X. X Xu, S. Wang, Y. X. Mi, H. Q. Zhao, Z. B. Zheng and X. L. Zhao, J. Coord. Chem., 2019, 72, 201-217.

43. Y. Zheng, D. Y. Zhang, H. Zhang, J. J. Cao, C. P. Tan, L. N. Ji and Z. W. Mao, Chem. Eur. J., 2018, 24, 18971-18980.

44. D. Reha, M. Kabelac, F. Ryjacek, J. Sponer, J. E. Sponer, M. Elstner and S. Suhai, J. Am. Chem. Soc., 2002, 124, 3366-3376.

45. N. Kurita and K. Kobayashi, Comput. Chem., 2000, 24, 351-357.

46. X. L. Zhao, M. J. Han, A. G. Zhang and K. Z. Wang, J. Inorg. Biochem., 2012, 107, 104-110.

47. D. Řeha, M. Kabelá, F. Ryjáek, J. Šponer, J. E. Šponer, M. Elstner, S. Suhai and P. Hobza, J. Am. Chem. Soc., 2002, 124, 3366-3376. 
